\title{
Retraction Note to: Decellularized scaffolds containing hyaluronic acid and EGF for promoting the recovery of skin wounds
}

\author{
Zhengzheng $\mathrm{Wu}^{1} \cdot$ Yan Tang ${ }^{2} \cdot$ Hongdou Fang ${ }^{1} \cdot{\text { Zhongchun } \mathrm{Su}^{1} \cdot \mathrm{Bin}_{\mathrm{Xu}^{3}} \cdot{\text { Yongliang } \mathrm{Lin}^{3}}^{3} \text { Peng Zhang }}^{3} \cdot$ \\ Xing Wei ${ }^{1}$
}

Published online: 26 May 2021

(c) The Author(s) 2021

\section{Correction to: Journal of Materials Science: Materials in Medicine (2015) 26:59 \\ https://doi.org/10.1007/s10856-014-5322-1}

The Editor-in-Chief has retracted this article [1] because it contains material that substantially overlaps with two other articles [2,3].

Author Xing Wei agrees to this retraction but not to the wording of the retraction notice. The editor was not able to obtain a current email address for any of the other authors.

Open Access This article is licensed under a Creative Commons Attribution 4.0 International License, which permits use, sharing, adaptation, distribution and reproduction in any medium or format, as long as you give appropriate credit to the original author(s) and the source, provide a link to the Creative Commons license, and indicate if changes were made. The images or other third party material in this article are included in the article's Creative Commons license, unless indicated otherwise in a credit line to the material. If material is not included in the article's Creative Commons license and your intended use is not permitted by statutory regulation or exceeds the permitted use, you will need to obtain permission directly from the copyright holder. To view a copy of this license, visit http://creativecommons. org/licenses/by/4.0/.

\section{References}

1. Wu Z, Tang Y, Fang H. et al. Decellularized scaffolds containing hyaluronic acid and EGF for promoting the recovery of skin wounds. J Mater Sci: Mater Med. 2015;26:59. https://doi.org/10. 1007/s10856-014-5322-1.

2. Wu Z, Fan L, Xu B, Lin Y, Zhang P, Wei X. Retracted: Use of decellularized scaffolds combined with hyaluronic acid and basic fibroblast growth factor for skin tissue engineering. Tissue Eng Part A. 2015;21:390-402. https://doi.org/10.1089/ten.tea.2013.0260.

3. Su Z, Ma H, Wu Z, Zeng H, Li Z, Wang Y, Liu G, Xu B, Lin Y, Zhang P, Wei X. Enhancement of skin wound healing with decellularized scaffolds loaded with hyaluronic acid and epidermal growth factor. Materials Science and Engineering: C. 2014;44:440-8. https:// doi.org/10.1016/j.msec.2014.07.039.

These authors contributed equally: Zhengzheng Wu, Yan Tang, Hongdou Fang, Zhongchun Su

Xing Wei

wei70@ hotmail.com

1 Key Lab for Genetic Medicine of Guangdong Province, National Engineering Research Center of Genetic Medicine, Institute of Biomedicine, Jinan University, Guangzhou 510632, Guangdong, China

2 Multidisciplinary Research Center, College of Science, Shantou University, Shantou 515063, Guangdong, China

3 Grandhope Biotech Co., Ltd., Building D, \#408, Guangzhou International Business Incubator, Guangzhou Science Park, Guangzhou 510663, Guangdong, China 